\title{
The Use of Peripheral $\mu$-Opioid Receptor Antagonists (PAMORA) in the Management of Opioid-Induced Constipation: An Update on Their Efficacy and Safety
}

This article was published in the following Dove Press journal:

Drug Design, Development and Therapy

\author{
Joseph V Pergolizzi Jr' \\ Paul J Christo ${ }^{2}$ \\ Jo Ann LeQuang' \\ Peter Magnusson ${ }^{3,4}$ \\ 'NEMA Research, Inc., Naples, FL, USA; \\ ${ }^{2}$ Division of Pain Medicine, Department \\ of Anesthesiology and Critical Care \\ Medicine, Johns Hopkins Medicine, \\ Baltimore, ML, USA; ${ }^{3}$ Cardiology \\ Research Unit, Department of Medicine, \\ Karolinska Institute, Stockholm, Sweden; \\ ${ }^{4}$ Centre for Research and Development, \\ Uppsala University/Region, Gävleborg, \\ Sweden
}

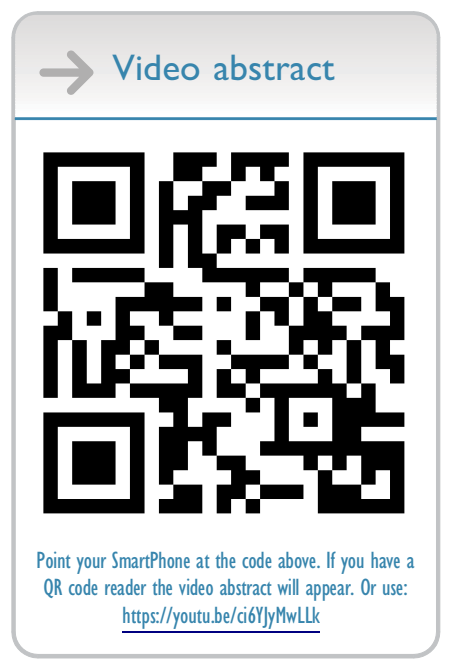

Correspondence: Joseph V Pergolizzi Jr NEMA Research, Inc., Naples, FL, USA Email jpjmd@msn.com

\begin{abstract}
Peripherally acting $\mu$-opioid receptor antagonists (PAMORAs) constitute a class of drugs which reverse opioid-induced constipation (OIC) with similar opioid analgesic effects. OIC differs from other forms of constipation in that it is an iatrogenic condition that occurs when an opioid acts on the dense network of $\mu$-opioid receptors in the enteric system, which affect a variety of functions including gastrointestinal motility, secretion, and other factors that can cause bowel dysfunction. Unfortunately, laxative products, bowel regimens, dietary changes, and lifestyle modifications have limited effectiveness in preventing OIC, Opioidassociated adverse effect which occurs in $40 \%$ to $80 \%$ of opioid patients and may led to cessation of the treatment. PAMORAs are $\mu$-receptor opioid antagonists specifically developed so that they have very limited ability to cross the blood-brain barrier and thus they are able to antagonize peripheral but not central $\mu$-opioid receptors. PAMORAs are designed to have no effect on the analgesic benefits of opioid pain relievers but to relieve but antagonizing the effects of the opioid in the gastrointestinal system. The three main PAMORAS are methyltrexone (oral or parenteral), naldemedine (oral only), and naloxegol (oral only). Clinical studies demonstrate the safety and efficacy of these agents for alleviating constipation without diminishing the analgesic effect of opioid therapy. The aim of this narrative review to update the current status of PAMORAs for treating OIC in terms of safety and efficacy.
\end{abstract}

Keywords: constipation, methylnaltrexone, naldemedine, naloxegol, opioid antagonism, opioid-associated bowel disorder, opioid-associated side effects, pain

\section{Plain Language Summary}

Constipation is a common and distressing side effect of opioids. It occurs because opioid receptors are found not only in the brain and along the spinal cord but also in the gut. When an opioid acts as specific $\mu$-opioid receptors in the gastrointestinal system, it can interfere with gastric motility, that is, the body's ability to move waste material through the intestines. A new type of drug has been developed to help reduce the effect of opioids in the gut without affecting how opioids work in the brain and spine. This allows the gastrointestinal system to function normally without decreasing the pain relief that opioids promote in the brain and spinal cord. These drugs are called peripherally acting $\mu$-opioid receptor antagonists or PAMORAs. They work differently than conventional laxatives because opioid-associated constipation is different than ordinary constipation. There are three main PAMORAs which are taken in addition to opioids in people who suffer from opioid-associated constipation. These are methyltrexone, naldemedine, and naloxegol. 
Methylnaltrexone is available as an injection or an oral tablet; the other drugs are available in oral formulation only. In clinical studies, PAMORAs reduce constipation without reducing pain relief provided by opioids.

\section{Introduction}

Peripherally acting $\mu$-opioid receptor antagonists (PAMORAs) represent a novel class of drugs that are designed to reverse opioid-induced constipation (OIC) without compromising opioid analgesic effects. OIC differs from other forms of constipation in that it is an iatrogenic condition that occurs when an opioid acts on the dense network of $\mu$-opioid receptors in the enteric system, which affect a variety of functions including gastrointestinal motility, secretion, and other factors that can cause bowel dysfunction. ${ }^{1}$ Conventional laxative products, bowel regimens, dietary changes, and lifestyle modifications have limited effectiveness in treating OIC, as they do not address the fundamental cause of OIC which differs from typical constipation. ${ }^{2-4}$ Long-term exposure to opioids may result in OIC characterized by infrequent bowel movements, hard dry stools, straining to evacuate the bowels, and a sense of incomplete bowel emptying. ${ }^{5}$ OIC is a frequently reported and distressing opioid-associated adverse effect which occurs in $40 \%$ to $80 \%$ of opioid patients, ${ }^{2,6,7}$ and may cause patients to discontinue or at least temporarily stop taking opioids to obtain temporary relief. ${ }^{2}$ The burden of OIC to the healthcare system and to patients is substantial. ${ }^{8}$ While many opioid-associated adverse effects diminish or even resolve with prolonged opioid exposure and resulting tolerance, this does not occur with OIC. ${ }^{2}$

PAMORAs are $\mu$-receptor opioid antagonists specifically developed so that they have very limited ability to cross the blood-brain barrier and thus they are able to antagonize peripheral but not central $\mu$-opioid receptors. 9 PAMORAs are designed to have no effect on the analgesic benefits of opioid pain relievers but to relieve but antagonizing the effects of the opioid in the gastrointestinal system.

Several PAMORAs have been developed but not all have come to commercial fruition. Over time, the safety and efficacy of three main PAMORAs, methylnaltrexone, naldemedine, and naloxegol have been established in a variety of studies, including large randomized controlled trials. No head-to-head clinical trials among these agents have been published. It is the aim of this narrative review to update the current status of PAMORAs for treating OIC in terms of safety and efficacy.

\section{Materials and Methods}

The main database used for searches was the National Institutes of Medicine Medline (PubMed) system. The PubMed database was searched for the term "peripherally-acting $\mu$-opioid receptor antagonist" using the delimiter "clinical trial" and yielded 39 articles. Another search for "PAMORA" and "clinical trial" found 3 results. The authors searched "opioid-induced constipation" and clinical trials and found 97 results. Then the Web of Science database was searched for "peripherallyacting $\mu$-opioid receptor antagonist" and "clinical trial" and found 13 results. The same database was searched for "opioid-induced constipation" and "clinical trial" and found 96 results. The Cochrane Database of Systematic Reviews was searched for "peripherally acting muopioid receptor antagonist" with 65 results, none of which were Cochrane systematic reviews but rather related articles. When the term "opioid-induced constipation" was searched in the Cochrane database, there was one result returned. All searches were conducted on October 18, 2019. There was considerable overlap among the findings, that is articles that appeared in one search often turned up in other searches. This resulted in 48 articles which were clinical trials or meta-analyses. When appropriate, this was supplemented with selected sources from the bibliographies of these articles to provide background and relevant information.

We used only articles in English that were available through these database systems. We limited clinical trials to those published in the past 10 years as we wished to provide an "update" on PAMORAs rather than a comprehensive history. The authors utilized the bibliographies of these articles and general searches for background information as needed.

\section{Results}

The safety and efficacy of PAMORAs has been well documented in the literature and subsequent analyses. Three main PAMORAs have emerged as clinically important and there are important differences among them in terms of mechanism of action, formulation, and price. Without head-to-head trials, it can be difficult to compare these agents. 


\section{Methylnaltrexone Bromide}

Methylnaltrexone is a methylated form of naltrexone. The addition of a methyl group on the amine ring of the molecule creates a more polarized compound with less lipophilicity than the parent agent, and the methylation greatly restricts the ability of the molecule to pass through the blood-brain barrier. ${ }^{10}$ Methylnaltrexone was originally administered as a subcutaneous injection but recently an oral formulation has been developed. ${ }^{11}$ When it was first introduced to market in 2014, it was made a Schedule II controlled substance, because it was similar in structure to noroxymorphone, but that has since been rescinded. ${ }^{12}$ Subcutaneous methylnaltrexone is typically used in the hospital setting or as rescue medication for outpatients with OIC. Dosing may be weight based or fixed. ${ }^{13}$

Methylnaltrexone was first indicated for the treatment of OIC in patients in palliative care with advanced illness and then later the indication was expanded to include patients with chronic noncancer pain. There is indirect evidence that a small amount of methylnaltrexone has centrally mediated effects, that is, may cross the blood-brain barrier. ${ }^{14}$ Methylnaltrexone is the only PAMORA with no clinically relevant cytochrome P450 (CYP450) drug-drug interactions. It is available in two formulations (subcutaneous injection and oral formulation). Methylnaltrexone may be used for maintenance therapy, rescue, and it has been studied with concomitant laxative therapy.

\section{Methylnaltrexone in Cancer Patients}

The use of subcutaneous methylnaltrexone in OIC patients with cancer who are not terminally ill was evaluated in a single-dose Phase II trial. ${ }^{15}$ Patients were included if their prognosis $\geq 3$ months and they had $<3$ bowel movements per week. In this study of 12 patients, $33.3 \%(n=4)$ had a rescue-free bowel movement (RFBM) within four hours and $41.7 \%$ within $24 \mathrm{hrs}$. By $48 \mathrm{hrs}, 83.3 \%$ had an RFBM and difficulty in evacuating the bowels improved significantly over $48 \mathrm{hrs}(\mathrm{p}=0.029)$, with patients tolerating the drug well. ${ }^{15}$

In a multicenter placebo-controlled study conducted in nursing homes, hospices, and other residential palliative care centers, 133 patients with OIC and advanced illness (including but not limited to cancer) were evaluated using $0.15 \mathrm{mg} / \mathrm{kg}$ subcutaneous methylnaltrexone per day or every other day over two weeks. ${ }^{16,17}$ More methylnaltrexone patients had a RFBM within four hours of the first dose compared to placebo patients, $48.4 \%$ vs $15.5 \%$. Most adverse events were mild to moderate and serious adverse events in all groups were deemed associated with the patients' underlying disease rather than the treatment drug. ${ }^{16,17}$ This study was followed by a multicenter openlabel extension study over 12 weeks $(\mathrm{n}=82) .{ }^{10}$ Patients were first administered $0.15 \mathrm{mg} / \mathrm{kg}$ of methylnaltrexone subcutaneously as a first dose which was then adjusted as needed to $0.075,0.15$, or $0.30 \mathrm{mg} / \mathrm{kg}$. Patients were doses as needed, up to a maximum of one dose every $24 \mathrm{hrs}$. For the patients entering the extension study from the methylnaltrexone arm $(n=42)$, the response during the doubleblind phase $(45.3 \%)$ was similar to that achieved in the extension phase (45.5\% to $57.7 \%)$. For patients entering the extension study from the placebo arm of the doubleblind trial $(\mathrm{n}=40)$, the response rate increased from $10.8 \%$ during the double-blind study to $48.3 \%$ during the first month of the extension study. Response rates during the second and third months of the extension study for this subpopulation were $47.6 \%$ and $52.1 \%$, respectively. Median time to laxation was $<1 \mathrm{hr}$ (range 0 to $4 \mathrm{hrs}$ ) in the double-blind phase and remained the same in the openlabel phase. Every patient treated in the extension phase experienced at least one adverse event of which about half were deemed by investigators to be related to the study drug. Serious adverse events occurred in $43.9 \%$ and $39 \%$ of patients died but all deaths were consistent with their underlying disease and considered unrelated to the treatment. Only two serious adverse events (abdominal pain and muscle spasms) in two patients were considered possibly related to methylnaltrexone therapy. Pain scores remained stable over the course of the study. ${ }^{10}$

\section{Methylnaltrexone in Chronic Noncancer Pain Patients}

Noncancer pain patients with OIC were randomized to receive subcutaneous methylnaltrexone $12 \mathrm{mg}$ daily or every other day or placebo (once daily or once every other day) in a randomized Phase III trial with an openlabel extension in which all patients crossed over to receive methylnaltrexone $12 \mathrm{mg}$ as needed. ${ }^{18}$ At the first dose, $9.7 \%$ in the placebo group had a RFBM within four hours compared to $45.9 \%$ in the open-label phase who had a RFBM within four hours of the first dose of subcutaneous methylnaltrexone. When patients crossed over from the placebo group to the open-label phase with as-needed subcutaneous methylnaltrexone, the percentage of those with $\geq 3$ RFBM increased from $35 \%$ to $40 \%$. Adverse events were reported in $32.8 \%$ of the placebo patients during the randomized phase and $43.3 \%$ of the patients 
in the open-label phase (when they received subcutaneous methylnaltrexone as needed). ${ }^{18}$

A double-blind, placebo-controlled study of 460 chronic noncancer pain patients were administered $12 \mathrm{mg}$ subcutaneous methylnaltrexone once a day, once every other day, or placebo on the same schedule for four weeks; both $34.2 \%$ of both methylnaltrexone groups had a RFBM within four hours of the dose compared to $9.9 \%$ for placebo $(\mathrm{p}<0.001)$. Mean responses within four hours of receiving a dose of subcutaneous methylnaltrexone were $30.2 \%$ for both daily and every-other-day methylnaltrexone patients and $9.4 \%$ and $9.3 \%$ for placebo daily or every other day. ${ }^{19}$ Overall, methylnaltrexone patients had more RFBMs per week than placebo patients: 1.6 more for daily dosing $(\mathrm{p}<0.001)$ and 0.7 more for every-other-day dosing $(\mathrm{p}<0.011){ }^{19}$

In a post-hoc analysis of a double-blind study $(n=137)$ of chronic noncancer pain patients who received subcutaneous methylnaltrexone $12 \mathrm{mg}$ once a day for four weeks, it was found that $42.3 \%$ had an RFBM after $\geq 2$ of 4 doses and, within that subpopulation, $81 \%$ had $\geq 3$ RFBMs per week. ${ }^{20}$ Those who had an early response, that is an RFBM after two or more of the first four doses averaged 4.8 RFBM a week compared to 2.0 for the group with fewer than two responses out of four week $(p<0.0001)$. This suggests that an early response to two or more of the first four doses of methylnaltrexone predicts robust effectiveness over the duration of therapy. ${ }^{20}$

\section{Methylnaltrexone in Postsurgical Patients}

A double-blind randomized parallel-group placebo-controlled phase II study evaluated the use of subcutaneous methylnaltrexone $12 \mathrm{mg}$ once a day in 33 patients with acute OIC following an orthopedic surgery for four to seven postoperative days. ${ }^{21}$ Patients receiving methylnaltrexone had a bowel movement within $2 \mathrm{hrs}$ of dosing versus placebo (33.3\% vs $0 \%, \mathrm{p}=-0.021)$ or $4 \mathrm{hrs}(38.9 \%$ vs $6.7 \%, \mathrm{p}=0.046)$ with a median time to laxation of $15.8 \mathrm{hrs}$ for methylnaltrexone and $50.9 \mathrm{hrs}$ for placebo $(\mathrm{p}=0.020)$. Pain scores were similar in both methylnaltrexone and placebo patients with $33.3 \%$ of methylnaltrexone patients reporting at least one treatmentemergent adverse event compared to $26.7 \%$ in the placebo group. ${ }^{21}$ The use of methylnaltrexone for postsurgical pain is currently considered off label.

\section{Long-Term Use of Methylnaltrexone}

An open-label multicenter phase III study evaluated 1034 chronic noncancer pain patients with OIC taking subcutaneous methylnaltrexone $12 \mathrm{mg}$ once a day for 48 weeks.
Patients had significant improvement over baseline in mean number of weekly bowel movements, Bowel Movement Straining Score, Bristol Stool Scale score, and complete evacuation $\left(\mathrm{p}<0.001\right.$ for all) ${ }^{22}$ Adverse events were mostly mild to moderate and $15.2 \%$ of patients dropped out because of an adverse event.

\section{Oral Methylnaltrexone}

In a study of 803 adults with chronic noncancer pain and OIC on a regimen of $\geq 50 \mathrm{mg} /$ day oral morphine equivalents were randomized to one of four groups: once-daily oral methylnaltrexone 150,300 , or $450 \mathrm{mg}$ or placebo. ${ }^{23}$ Patients took this dose for four weeks and then as needed for eight weeks. Responders were defined as those who had at least three RFBMs a week with an increase of one RFBM over baseline for at least 3 of 4 weeks. There were significantly more responders in the methylnaltrexone groups 300 and $450 \mathrm{mg}(49.3 \% \mathrm{p}=0.03$ and $51.5 \%$, $\mathrm{p}=0.005)$ compared to placebo $(38.3 \%)$. The increase in the mean number of weekly RFBMs was 0.5 for 300 and $450 \mathrm{mg}$ methylnaltrexone $(\mathrm{p}=0.03$ and $\mathrm{p}=0.02$, respectively) compared to placebo. All doses of methylnaltrexone were well tolerated. ${ }^{23}$

An oral methylnaltrexone formulation was evaluated in 803 adults with OIC randomized to 150,300 , or $450 \mathrm{mg}$ oral methylnaltrexone or placebo daily for four weeks and then dosed as needed for the next eight weeks. ${ }^{23}$ Responders were considered those who had $\geq 3$ RFBM a week with an increase of $\geq 1$ RFBM a week over baseline and for $\geq 3$ of four weeks in the "as needed phase." The percentage of responders was $42.8 \%, 49.3 \%, 51.5 \%, 38.3 \%$ for oral methylnaltrexone $150 \mathrm{mg}, 300 \mathrm{mg}, 400 \mathrm{mg}$, and placebo, respectively, with significant improvement in $300 \mathrm{mg}$ and $400 \mathrm{mg}$ groups versus placebo during the study and in the as needed period as well. A statistically significant difference in efficacy emerged at the outset of the study between methylnaltrexone $450 \mathrm{mg}$ and $300 \mathrm{mg}$ which was largely maintained over the course of the study, leading investigators to state that $450 \mathrm{mg}$ oral methylnaltrexone was the more effective dose. ${ }^{23}$

\section{Methylnaltrexone as Rescue Therapy}

In a study using pooled data from two randomized, double-blind, placebo-controlled phase III studies $(\mathrm{n}=288)$, it was found that more than $50 \%$ of patients experienced a RFBM within four hours of the first dose of subcutaneous methylnaltrexone $(0.15$ or $0.30 \mathrm{mg} / \mathrm{kg}$ dose $)$ compared to $14.6 \%$ of placebo patients. ${ }^{24}$ 
Table I Adverse Events in Studies of Methylnatrexone for the Treatment of OIC. All Patients in These Trials Had OIC

\begin{tabular}{|c|c|c|c|c|}
\hline Study Drug & Patient Population & Safety Results & AE Severity & Comments \\
\hline $\begin{array}{l}\text { Anissian } 201 \mathrm{l}^{21} \\
\text { SQ MTX } 12 \mathrm{mg} \\
\text { QD } \\
\text { RCT }\end{array}$ & $\begin{array}{l}33 \mathrm{pt} \text { with acute OIC } \\
\text { following orthopedic } \\
\text { surgery }\end{array}$ & $\begin{array}{l}\text { AEs reported in } 33 \% \text { of } \mathrm{MTX} \text { and } 27 \% \text { of placebo pt } \\
\text { Most common AEs possibly related to study drug: } \\
\text { nausea, abdominal pain, diarrhea } \\
\mathrm{Gl} \text { adverse events occurred in } 17 \% \text { of MTX and } 7 \% \\
\text { of placebo pt }\end{array}$ & No serious AEs occurred & $\begin{array}{l}2 \text { pt in MTX group } \\
\text { discontinued the drug } \\
\text { No changes in } \\
\text { analgesia } \\
\text { No signs of OWS }\end{array}$ \\
\hline $\begin{array}{l}\text { Bull } 2015^{13} \\
\text { SQ MTX } 8 \text { or } \\
12 \mathrm{mg} / \mathrm{kg} \text { QOD } \\
\text { Placebo- } \\
\text { controlled with } \\
\text { OLE }\end{array}$ & $\begin{array}{l}230 \text { patients with } \\
\text { advanced illness in DB } \\
\text { study and I } 49 \text { entered } \\
\text { OLE }\end{array}$ & $\begin{array}{l}\text { AEs occurred in } 82 \% \text { of MTX and } 74 \% \text { of placebo pt in } \\
\text { RCT and in } 90.6 \% \text { of OLE pt } \\
\text { Most common AE in MTX pt was abdominal pain, } 33 \% \\
\text { vs } 17 \% \text { in RCT } \\
\text { In OLE most common AEs ( } \geq 5 \text { pt) deemed at least } \\
\text { possibly related to MTX were abdominal pain (15\%), } \\
\text { diarrhea ( } 7 \%) \text {, and flatulence ( } 3 \%)\end{array}$ & $\begin{array}{l}\text { No serious AEs in the RCT } \\
\text { or OLE were considered } \\
\text { related to MTX } \\
\text { Most side effects were mild } \\
\text { to moderate }\end{array}$ & $\begin{array}{l}\text { No clinically } \\
\text { meaningful changes in } \\
\text { pain, analgesia } \\
\text { reported in RCT or } \\
\text { OLE } \\
\text { OWS results not } \\
\text { reported }\end{array}$ \\
\hline $\begin{array}{l}\text { Chamberlain } \\
2009^{16} \\
\text { SQ } \\
\text { Methylnaltrexone } \\
0.15 \mathrm{mg} / \mathrm{kg} \text { every } \\
\text { other day for } 2 \\
\text { wk } \\
\text { RCT }\end{array}$ & $\begin{array}{l}\text { 7I patients with } \\
\text { advanced illness }\end{array}$ & $\begin{array}{l}\text { Abdominal pain, flatulence, nausea, increased body } \\
\text { temperature, dizziness occurred in } \geq 5 \% \text { more } \\
\text { MTX pt than placebo patients } \\
\text { Most common AEs were abdominal pain, flatulence, } \\
\text { vomiting }\end{array}$ & $\begin{array}{l}\text { Most AEs in both groups } \\
\text { were mild to moderate } \\
\text { Serious AEs occurred in both } \\
\text { active and control groups but } \\
\text { all were deemed related to } \\
\text { the underlying illness }\end{array}$ & $\begin{array}{l}\text { On the Himmelsbach } \\
\text { Withdrawal Scale, } \\
\leq 4 \% \text { of patients in } \\
\text { either group had } \\
\text { a change from none } \\
\text { to mild to moderate } \\
\text { I pt taking MTX had } \\
\text { severe OWS at day } \\
\text { I4 }\end{array}$ \\
\hline 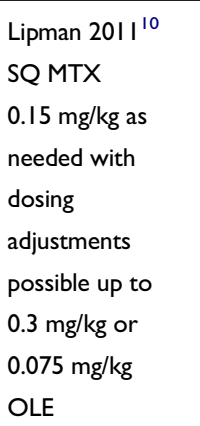 & $\begin{array}{l}82 \text { pt with advanced } \\
\text { illness who had } \\
\text { previously } \\
\text { participated in the } \\
\text { study reported below } \\
\text { under Thomas } 2008\end{array}$ & $\begin{array}{l}\text { Every pt experienced at least I AE with most } \\
\text { common AEs: abdominal pain ( } 30.5 \%) \text {, cancer } \\
\text { progression }(24.4 \%) \text {, nausea }(20.7 \%) \text { and vomiting } \\
(19.5 \%) \\
57 / 82 \mathrm{pt} \text { had GI AEs of which } 3 \text { I were possibly or } \\
\text { probably or definitely related to MTX and } 26 / 82 \\
\text { AEs were not }\end{array}$ & $\begin{array}{l}\text { Serious AEs occurred in } \\
43.9 \% \text { of pt but the most } \\
\text { common related to the } \\
\text { underlying disease (neoplasm } \\
\text { progression) } \\
\text { Serious AE deemed possibly } \\
\text { related to MTX occurred in I } \\
\text { pt (muscle spasms) }\end{array}$ & $\begin{array}{l}6 \text { pt discontinued } \\
\text { MTX because of AEs } \\
\text { No pt reported } \\
\text { clinically meaningful } \\
\text { changes in analgesia } \\
\text { or pain intensity } \\
\text { Most pt had no signs } \\
\text { or mild signs of OWS }\end{array}$ \\
\hline $\begin{array}{l}\text { Mori } 2017^{15} \\
\text { SQ MTX } \\
\text { Single-dose (not } \\
\text { stated) } \\
\text { Observational }\end{array}$ & 12 cancer patients & $\begin{array}{l}\text { No severe } A E s \text { at } 4 \mathrm{~h} \\
\text { I severe } A E \text { at } 24 \mathrm{~h} \text { (nausea) } \\
\text { I severe } A E \text { at } 48 \mathrm{~h} \text { (abdominal pain) } \\
\text { Most frequent } A E s \text { at } 4,24 \text {, and } 48 \text { h: mild to } \\
\text { moderate flatulence } \\
\text { No reports of injection site reaction. }\end{array}$ & $\begin{array}{l}\text { Most AEs were mild to } \\
\text { moderate }\end{array}$ & No signs of OWS \\
\hline $\begin{array}{l}\text { Nalamachu } \\
2015^{24} \\
\text { SQ MTX } \\
\text { Pooled analysis } \\
\text { from } 2 \text { RCTs }\end{array}$ & $\begin{array}{l}165 \text { pt with advanced } \\
\text { illness }\end{array}$ & $\begin{array}{l}\text { Any AE for MTX: } \\
0.15 \mathrm{mg} / \mathrm{kg}: 77 \% \\
0.30 \mathrm{mg} / \mathrm{kg}: 82 \% \\
\text { Pooled: } 79 \% \\
\text { Placebo: } 68 \% \\
\text { Most common AEs for MTX were abdominal pain } \\
\text { (28\% vs } 10 \% \text { placebo), flatulence ( } 7 \% \text { vs } 12 \% \\
\text { placebo), vomiting ( } 9 \% \text { vs } 8 \% \text { placebo), restlessness } \\
\text { (7\% MTX and placebo), peripheral edema ( } 4 \% \text { vs } 7 \% \\
\text { placebo), abdominal distension ( } 2 \% \text { vs } 6 \% \text { placebo), } \\
\text { and fall ( } 2 \% \text { vs } 6 \% \text { placebo) }\end{array}$ & $\begin{array}{l}\text { Most AEs were mild to } \\
\text { moderate, } 10 \% \text { were serious } \\
\text { and the most common of } \\
\text { which was neoplasm } \\
\text { progression (unrelated to } \\
\text { study drug). }\end{array}$ & $\begin{array}{l}\text { Analgesia and OWS } \\
\text { not reported } \\
\text { No discontinuations } \\
\text { reported }\end{array}$ \\
\hline
\end{tabular}


Table I (Continued).

\begin{tabular}{|c|c|c|c|c|}
\hline Study Drug & Patient Population & Safety Results & AE Severity & Comments \\
\hline $\begin{array}{l}\text { Rauck } 2017^{23} \\
\text { Oral MTX (150, } \\
300, \text { or } 450 \mathrm{mg}) \\
\text { QD for } 4 \mathrm{wk} \text { then } \\
\text { PRN for } 8 \mathrm{wk} \\
\text { RCT }\end{array}$ & $\begin{array}{l}803 \text { chronic } \\
\text { noncancer pain pt }\end{array}$ & $\begin{array}{l}\text { Over } 12 \text { wk, abdominal pain occurred in } 11 \% \text { MTX } \\
\text { vs } 9 \% \text { placebo pt; nausea } 6 \% \text { vs } 9 \% \text {; diarrhea } 8 \% \text { vs } \\
4 \% \\
\text { AEs were similar by dose to placebo: } \\
\text { MTX 150: } 86 \% \\
\text { MTX } 300: 87 \% \\
\text { MTX } 450: 86 \% \\
\text { Placebo: } 86 \%\end{array}$ & $\begin{array}{l}\text { Most AEs were mild to } \\
\text { moderate. } \\
\text { Serious AEs occurred in } 3 \% \\
\text { of MTX groups (pooled) vs } \\
4 \% \text { of placebo }\end{array}$ & $\begin{array}{l}\text { Those who } \\
\text { discontinued the drug } \\
\text { were similar by } \\
\text { group: } \\
\text { MTX 150: } 1 \% \\
\text { MTX 300: } 3 \% \\
\text { MTX 450: } 0 \\
\text { Placebo: } 2 \% \\
\text { Analgesia remained } \\
\text { similar across all } \\
\text { groups for } 12 \text { wk } \\
\text { OWS not reported }\end{array}$ \\
\hline $\begin{array}{l}\text { Thomas } 2008^{17} \\
\text { SQ MTX } 0.15 \mathrm{mg} / \\
\mathrm{kg} \text { every } \\
\text { other day for } 2 \mathrm{wk} \\
\text { Placebo } \\
\text { controlled } \\
\text { In the extension } \\
\text { phase, doses } \\
\text { could increase, as } \\
\text { needed, max } \\
0.3 \mathrm{mg} / \mathrm{kg}\end{array}$ & $\begin{array}{l}\text { I33 pt with advanced } \\
\text { illness }\end{array}$ & $\begin{array}{l}\text { Most commonly reported AEs in both groups ( } \geq 5 \% \\
\text { or more of pt affected): abdominal pain, flatulence, } \\
\text { nausea, increased body temperature, and dizziness } \\
\text { but were reported more in the MTX than placebo } \\
\text { group } \\
\text { Falls and hypotension occurred more often in the } \\
\text { placebo group }\end{array}$ & $\begin{array}{l}\text { Most AEs were mild to } \\
\text { moderate } \\
\text { Serious and severe AE } \\
\text { occurred in } 17 \% \text { and } 8 \% \text { of } \\
\text { MTX pt respectively and } 28 \% \\
\text { and } 13 \% \text { of placebo patients, } \\
\text { most of which were related } \\
\text { to the underlying disease } \\
\text { Life-threatening AE occurred } \\
\text { in } 16 \% \text { of MTX and I5\% of } \\
\text { placebo patients, all of which } \\
\text { were deemed related to the } \\
\text { underlying illness } \\
6 \% \text { of MTX and } 7 \% \text { of } \\
\text { placebo patients discontinued } \\
\text { the study drug during the } \\
\text { study }\end{array}$ & $\begin{array}{l}\text { The extension phase } \\
\text { of this study is } \\
\text { reported as Lipman }\end{array}$ \\
\hline $\begin{array}{l}\text { Viscusi } 2016^{19} \\
\text { SQ MTX (12 mg } \\
\text { QD, } 12 \mathrm{mg} \\
\text { QOD) in RCT } \\
\text { for } 4 \mathrm{wk}\end{array}$ & $\begin{array}{l}460 \text { patients with } \\
\text { noncancer pain in the } \\
\mathrm{RCT} \text {, of whom I } 34 \\
\text { entered the OLE and } \\
\text { crossed over to SQ } \\
\text { MTX } 12 \mathrm{mg} \text { PRN }\end{array}$ & $\begin{array}{l}33 \% \text { of RCT and } 43 \% \text { of OLE pt had an AE. } \\
\text { In the OLE, the most common AEs were abdominal } \\
\text { pain, nausea, and urinary tract infections }\end{array}$ & $\begin{array}{l}\text { Serious AEs were reported } \\
\text { by I pt in RCT and } 4 \mathrm{pt} \text { in } \\
\text { OLE, none of which were } \\
\text { considered MTX related }\end{array}$ & $\begin{array}{l}\text { Abdominal pain } \\
\text { typically decreased } \\
\text { over time } \\
\text { Analgesia changes and } \\
\text { OWS not reported }\end{array}$ \\
\hline $\begin{array}{l}\text { Webster } 2017^{22} \\
\text { SQ MT } 12 \mathrm{mg} \\
\text { QD, } 48 \mathrm{wk} \\
\text { Open-Label }\end{array}$ & $\begin{array}{l}1034 \text { pt with } \\
\text { noncancer pain }\end{array}$ & $\begin{array}{l}79 \% \text { of pt reported an } \mathrm{AE} \text {, most } \mathrm{AEs} \text { were } \mathrm{GI}(24 \% \\
\text { abdominal pain, } 16 \% \text { diarrhea, } 7 \% \text { vomiting, } 7 \% \\
\text { upper abdominal pain, } 6 \% \text { flatulence) } \\
11 \% \text { reported a psychiatric disorder (anxiety, } \\
\text { depression, insomnia) }\end{array}$ & $\begin{array}{l}\text { Most mild to moderate with } \\
6 \% \text { severe. The most } \\
\text { common severe AE was } \\
\text { abdominal pain ( } 4 \% \text { ). } \\
10 \% \text { reported serious AEs of } \\
\text { which four patients had AEs } \\
\text { possibly related to MTX }\end{array}$ & $\begin{array}{l}\text { I5\% of pt } \\
\text { discontinued because } \\
\text { of AEs } \\
\text { I.5\% reported } \\
\text { a cardiac AE but no } \\
\text { clear causal link to } \\
\text { MTX could be found } \\
\text { No sign of OWS } \\
\text { Analgesia changes not } \\
\text { reported }\end{array}$ \\
\hline
\end{tabular}

Note: Data from these studies. ${ }^{10,13,15-18,21-24}$

Abbreviations: AE, adverse event; GI, gastrointestinal; h, hour; max, maximum; mg, milligram; mg/kg, milligram per kilogram; MTX, methylnaltrexone; OLE, openlabel extension (study); OWS, opioid withdrawal syndrome; pt, patient(s); QD, once a day; QOD, once every other day; RCT, randomized clinical trial; SQ, subcutaneous; wk, week. 


\section{Adverse Events Associated with Methylnaltrexone}

Adverse events have been reported in these trials which are sometimes caused by the patient's underlying illness or other factors. See Table 1.

A post-hoc analysis of patients from two double-blind placebo-controlled clinical trials $(n=288)$ utilized patient descriptions in order to evaluate adverse events associated with methylnatrexone. ${ }^{25}$ Most patients called these effects "cramping" or "abdominal cramps" and considered them mild to moderate in intensity. These cramping symptoms did not impact the patients' global assessment of their pain. Adverse events were most intense and noticeable with the first dose and their severity diminished over the course of treatment. There emerged a correlation between reported abdominal pain and the rapidity of an RFBM following the first dose. Methylnaltrexone patients reporting abdominal pain had an RFBM in the first four hours after dosing in $80 \%$ of cases compared to $47.2 \%$ of methylnaltrexone patients who did not report abdominal pain. A similar pattern occurred in placebo patients; 33\% of those reporting abdominal pain had an RFBM within four hours of the first dose compared to $13.7 \%$ who did not report any pain. ${ }^{25}$

\section{Methylnaltrexone Dosing}

Results of two Phase IV randomized placebo-controlled studies of subcutaneous methylnaltrexone with OIC patients with advanced illness showed the use of fixed rather than weight-based dosing of methylnaltrexone. ${ }^{13}$ About two-thirds of the study population had cancer, but pulmonary disease, cardiovascular disease, or a terminal neurological disorder was also represented. Patients received a fixed dose of either 8 or $12 \mathrm{mg}$ methylnaltrexone (based on body weight) or placebo every other day for two weeks. At the completion of the two-week studies, patients could continue in an open-label extension study with methylnaltrexone administered as needed (PRN). The primary endpoint of the studies was percentage of patients who had an RFBM within four hours after $\geq 2$ of the first four doses of methylnaltrexone in the first week. The studies enrolled 116 and 114 patients, respectively, and 149 patients continued to the open-label extension. Taken together, methylnaltrexone patients were significantly more likely to achieve the primary endpoint (62.9\% vs $9.6 \%, \mathrm{p}<0.0001)$. The median time to RFBM after the first dose was $0.8 \mathrm{hrs}$ for methylnaltrexone compared to 23.6 hrs for placebo $(\mathrm{p}<0.0001) .^{13}$
In a meta-analysis $(n=1239,6$ studies $)$ of the efficacy of methylnaltrexone for treatment of OIC, the true risk difference between methylnaltrexone and placebo in the frequency of RFBMs is between 0.267 and 0.385 , which is significant $(\mathrm{p}<0.0001){ }^{26}$ This significance applied to doses of 0.15 and $0.30 \mathrm{mg} / \mathrm{kg} /$ day dosed every other day as well as doses of $12 \mathrm{mg} /$ day.

\section{Naldemedine}

Cleared for market release in the United States in 2017, naldemedine is the newest of the PAMORA drugs. A derivative of naltrexone with selectivity in the periphery, naledemedine is a $\mathrm{P}$-glycoprotein substrate metabolized via the CYP3A enzyme. As such, drug-drug interactions may occur in the setting of CYP3A4 inhibitors (diltiazem, verapamil, clarithromycin, erythromycin, others, and foods such as grapefruit). Naldemedine is once-daily oral agent indicated for treating $\mathrm{OIC}$ in cancer patients and for chronic noncancer pain patients. Naldemedine has been extensively studied in a series of clinical trials under the heading COMPOSE.

\section{The COMPOSE Suite of Studies}

A suite of large, multicenter, international studies to evaluate the safety and efficacy of naldemedine have been published. In all of these studies, naldemedine was effective but associated with adverse events, most of which were mild to moderate. These studies evaluated shortterm and long-term use of naldemedine in two main patient populations: those with chronic noncancer pain and those with cancer pain. See Table 2.

Published in 2013, the COMPOSE-1 and COMPOSE-2 studies demonstrated that naldemedine therapy had a higher response rate for OIC than placebo in chronic noncancer pain patients and was generally well tolerated although it had a higher rate of adverse events than placebo ( $15 \%$ vs $7 \%$ and $16 \%$ vs $7 \%$ for COMPOSE- 1 and 2 , respectively). ${ }^{27}$

The COMPOSE-4 study evaluated the efficacy of naldemedine for OIC treatment in cancer patients as well as how naldemedine affected quality of life. ${ }^{28}$ Patients received $0.2 \mathrm{mg}$ of oral naldemedine per day, and the dose of naldemedine could be reduced or discontinued if adverse events occurred. Patients had approximately 1 spontaneous bowel movement (SBM) per week upon enrollment. ${ }^{28}$ More patients in the naldemedine group experienced three or more complete spontaneous bowel movements (CSBM) in a week compared to placebo patients $(40.2 \%$ vs $12.5 \%$, 
Table 2 An Overview of the COMPOSE Studies of Naldemedine

\begin{tabular}{|c|c|c|c|}
\hline Trial & Population & Description & Results \\
\hline $\begin{array}{l}\text { COMPOSE-I } \\
\text { Phase III } \\
\text { I } 2 \text { weeks }\end{array}$ & $\begin{array}{l}547 \text { chronic noncancer } \\
\text { pain patients }\end{array}$ & $\begin{array}{l}\text { Multicenter, randomized, } \\
\text { double-blind, placebo- } \\
\text { controlled, parallel group }\end{array}$ & $\begin{array}{l}47.6 \% \text { of naldemedine vs } 34.6 \% \text { of placebo group } \\
\text { were responders }\end{array}$ \\
\hline $\begin{array}{l}\text { COMPOSE-2 } \\
\text { Phase III } \\
\text { I } 2 \text { weeks }\end{array}$ & $\begin{array}{l}553 \text { chronic noncancer } \\
\text { pain patients }\end{array}$ & $\begin{array}{l}\text { Multicenter, randomized, } \\
\text { double-blind, placebo- } \\
\text { controlled, parallel-group }\end{array}$ & $\begin{array}{l}52.5 \% \text { of naldemedine vs } 33.6 \% \text { of placebo group } \\
\text { were responders }\end{array}$ \\
\hline $\begin{array}{l}\text { COMPOSE-3 } \\
\text { Phase III } \\
52 \text { weeks }\end{array}$ & $\begin{array}{l}2414 \text { chronic noncancer } \\
\text { pain }\end{array}$ & $\begin{array}{l}\text { Multicenter, randomized, } \\
\text { double-blind, placebo- } \\
\text { controlled study }\end{array}$ & $\begin{array}{l}\text { Adverse events and treatment-emergent adverse } \\
\text { events similar between naldemedine and placebo. } \\
\text { Quality of life significantly better with naldemedine }\end{array}$ \\
\hline $\begin{array}{l}\text { COMPOSE-4 } \\
\text { Phase III } \\
2 \text { weeks }\end{array}$ & 193 cancer patients & $\begin{array}{l}\text { Randomized, double-blind, } \\
\text { placebo- controlled study }\end{array}$ & $\begin{array}{l}\text { Significantly more responders with naldemedine } \\
0.2 \mathrm{mg} \text { than placebo }\end{array}$ \\
\hline $\begin{array}{l}\text { COMPOSE-5 } \\
\text { Open-label extension study of } \\
\text { COMPOSE-4 } \\
12 \text { weeks }\end{array}$ & $|3|$ cancer patients & Safety study & $\begin{array}{l}80.2 \% \text { of patients experienced at least one treatment- } \\
\text { emergent adverse event, no analgesic deficits. }\end{array}$ \\
\hline $\begin{array}{l}\text { COMPOSE-6 } \\
\text { Phase III } \\
\text { Safety study } \\
48 \text { weeks }\end{array}$ & 43 chronic noncancer pain & Safety study & $\begin{array}{l}\text { Treatment-emergent adverse events occurred in } 88 \% \\
\text { of patients; } 81.0 \% \text { of patients were responders }\end{array}$ \\
\hline $\begin{array}{l}\text { COMPOSE-7 } \\
\text { Phase III } \\
\text { Safety study } \\
48 \text { weeks }\end{array}$ & 10 chronic noncancer pain & Safety study & $\begin{array}{l}\text { Treatment-emergent adverse events occurred in } 90 \% \\
\text { of patients; } 90.0 \% \text { of patients were responders }\end{array}$ \\
\hline
\end{tabular}

$\mathrm{p}<0.0001)$. The median time to onset of relief with naldemedine vs placebo was 4.7 vs $26.6 \mathrm{hrs}$ for an SBM and 24.0 versus $218.5 \mathrm{hrs}$ for CSBM (both $\mathrm{p}<0.0001$ ). ${ }^{28}$ Measured on the Patient Assessment of Constipation-Symptoms (PAC-SYM) and Patient Assessment of Quality of Life (PAC-QOL) surveys, there were no significant changes over baseline at 15 days with naldemedine or placebo in COMPOSE-4 but in COMPOSE-5 naldemedine patients had significant improvement over baseline in both surveys at all points in time $(\mathrm{p}<0.0001$, all $)$. No deficits in pain control were reported. ${ }^{28}$ This two-week study was followed by COMPOSE-5, an open-label, 12-week observational extension study to evaluate naldemedine safety and quality of life of 131 subjects from COMPOSE-4.

The COMPOSE-5 open-label extension study from COMPOSE-4 found $80.2 \%$ of patients reported at least one treatment-emergent adverse event, of which diarrhea was the most commonly reported. Naldemedine had no clinically relevant effect on pain control and patients did not experience symptoms of opioid withdrawal. ${ }^{28}$
These were followed by two long-term studies from Japan, COMPOSE-6 and COMPOSE-7, which enrolled chronic noncancer pain patients for 48 weeks (43 and 10 patients, respectively). ${ }^{29}$ Treatment-emergent adverse events occurred in $88 \%$ and $90 \%$ of patients, respectively. Pain relief and symptoms of opioid withdrawal were stable in patients over the course of the study. Responders based on frequency of bowel movements were $81.0 \%$ in COMPOSE-6 (95\% confidence interval, 65.9-91.4\%) and 90.0\% in COMPOSE-7 (95\% confidence interval, 55.5-99.7\%). ${ }^{29}$

\section{Other Naldemedine Studies}

The long-term effects of naldemedine for OIC in chronic noncancer pain patients on opioid therapy was evaluated in a randomized, 52-week, double-blind, phase III study in which patients were randomized to oral naldemedine $0.2 \mathrm{mg}$ once daily or placebo $(\mathrm{n}=1246){ }^{30}$ The primary endpoint was treatment-emergent adverse events which occurred in $68.4 \%$ of naldemedine and $72.1 \%$ of placebo patients $(-3.6 \%, 95 \%$ confidence interval, -8.7 to 1.5$)$. 
Treatment-emergent adverse events that caused the patient to drop out of the study occurred in $6.3 \%$ of naldemine and $5.8 \%$ of placebo patients $(0.5 \%, 95 \%$ confidence interval, -2.2 to 3.1$)$. The groups had no statistically significant differences in withdrawal symptoms or pain intensity. Naldemedine patients had more frequent bowel movements and better quality of life at all time points in the study compared to the placebo patients $(\mathrm{p} \leq 0.0001) .^{30}$

A meta-analysis of randomized clinical trials $(n=2762 ; 6$ studies) found SBM responders were significantly more frequent in naldemedine than placebo groups $(56.4 \%$ vs $34.7 \%$, $\mathrm{p}<0.00001$ ) with no statistically significant difference between naldemedine groups and placebo in terms of side effects. ${ }^{31}$

\section{Dosing and Pharmacokinetics of Naldemedine}

Naldemedine's pharmacokinetic properties were evaluated in two randomized, double-blind, placebo-controlled Phase I studies in healthy volunteers. ${ }^{32}$ There was a single escalating dose study where patients received one dose of naldemedine (1 to $100 \mathrm{mg}$ ) or placebo (42 naldemedine and 14 placebo patients). There was also a multiple-dose study where subjects received 3 to $30 \mathrm{mg}$ naldemedine daily $(n=27)$ or placebo $(n=9)$ for 10 days. On the first day of the single-dose study, plasma concentrations were 1.98 to $2510 \mathrm{ng} / \mathrm{mL}$, peaking at $0.5 \mathrm{hrs}$ with $15.9 \%$ to $20.5 \%$ excreted in the urine; in contrast, on the tenth day of the multiple-dose study, plasma concentrations ranged from 73.8 to $700 \mathrm{ng} / \mathrm{mL}$, peaking at 0.5 to $0.75 \mathrm{hrs}$, with $19.1 \%$ to $19.7 \%$ excreted in the urine. No major safety or tolerability issues emerged at any doses. Adverse events were not dose dependent and gastrointestinal adverse events were more common with naldemedine than placebo. ${ }^{32}$

A randomized, double-blind, multicenter, dose-finding study of naldemedine evaluated 225 cancer patients who had been on a stable opioid analgesic regimen for at least two weeks and had at least one symptom of constipation despite the use of laxatives and no more than five spontaneous bowel movements (SBMs) in the past 14 days. ${ }^{33}$ Patients were randomized to one of four groups: placebo or oral naldemedine at $0.1 \mathrm{mg}, 0.2 \mathrm{mg}$, or $0.4 \mathrm{mg}$. The primary endpoint of this study was the change in SBM frequency/week compared to baseline. All naldemedine groups had more frequent weekly SBMs than placebo patients. Treatment-emergent adverse events were more frequent with naldemedine than placebo $(66.1 \%, 67.2 \%$, and $78.6 \%$ for naldemedine $0.1,0.2$, and $0.4 \mathrm{mg}$, respectively, versus $51.8 \%$ for placebo). The most frequently reported adverse event was diarrhea. ${ }^{33}$
A similar phase IIb study randomized 244 chronic noncancer pain patients in a four-week study of $0.1,0.2$, or $0.4 \mathrm{mg}$ of oral naldemedine daily compared to placebo. $^{34}$ The weekly frequency of SBM was higher with naldemedine $0.2 \mathrm{mg}(3.37, \mathrm{p}=0.0014)$ and $0.4 \mathrm{mg}$ (3.64, $\mathrm{p}=0.0003$ ) but not with $0.1 \mathrm{mg}(1.98, \mathrm{p}=0.3504)$. Patients with three or more SBMs per week and an increase of at least one SBM a week over baseline for at least two weeks of treatment were deemed responders; $71.2 \%$ of naldemedine $0.2 \mathrm{mg}$ and $66.7 \%$ of naldemedine $0.4 \mathrm{mg}$ patients were responders $(\mathrm{p}=0.0005$ and $\mathrm{p}=0.003$, respectively) as were $52.5 \%$ of naldemine $0.1 \mathrm{mg}$ patients (not significant) and $39.3 \%$ of the placebo group. Adverse events increased with naldemedine group but were mostly mild to moderate in severity. This study concluded that oral naldemedine $0.2 \mathrm{mg}$ per day was the optimal dose. ${ }^{34}$

A phase IIb trial of OIC cancer patients was conducted comparing oral once-a-day naldemedine $0.1,0.2$, or $0.4 \mathrm{mg}$ and placebo over 14 days. ${ }^{33}$ All naldemedine groups had significantly more SBMs per week than placebo ( $\mathrm{p}<0.05$ for all) and improvement in straining during evacuation occurred in naldemedine 0.2 and $0.4 \mathrm{mg}$ daily vs placebo, but not for $0.1 \mathrm{mg}$ naldemedine. Improvements occurred in dose-dependent fashion. Treatment-emergent adverse events were common and occurred in $66.1 \%$, $67.2 \%, 78.6 \%$, and $51.8 \%$ of naldemedine $0.1,0.2$, $0.4 \mathrm{mg}$ and placebo, respectively. ${ }^{33}$

\section{Naloxegol}

Naloxegol is a PEGylated derivate of naloxone created as an oral PAMORA. In the United States, naloxegol is approved for treating adults with OIC and chronic noncancer pain, while in the European Union, naloxegol is also approved for adults who have had an inadequate response to laxative therapy. ${ }^{35}$ Available in doses of 12.5 and $25 \mathrm{mg}$ it has predictable pharmacokinetics even over a wide range of doses (up to a single dose of $1000 \mathrm{mg}$ ) with rapid absorption and mean time to plasma concentration $<2$ hrs. Steady state occurs at about two or three days with minimal observed accumulation of the agent. Naloxegol is metabolized via the CYP450-3A4 enzymatic system and antagonizes the peripheral but not central effects of morphine. ${ }^{36}$

\section{Naloxegol in Cancer Patients}

Naloxegol is not indicated for the treatment of OIC in cancer pain patients. The KODIAC-06 study was designed 
to evaluate naloxegol in cancer patients but had to be discontinued early because of lack of patient enrollment. ${ }^{37}$

\section{Naloxegol in Chronic Noncancer Pain Patients}

In two identical phase III double-blind placebo-controlled studies (652 and 700 patients, respectively), chronic noncancer pain patients with OIC were administered 12.5 or $25 \mathrm{mg}$ daily of naloxegol or placebo for 12 weeks. ${ }^{38}$ The primary endpoint was $\geq 3$ SBM a week with an increase of $\geq 1$ SBM over baseline for $9 / 12$ weeks and $\geq 3$ of the final four weeks of the study. Naloxegol $25 \mathrm{mg}$ was significantly superior to placebo for the primary endpoint: $44.4 \%$ vs $29.4 \%, p=0.001$ for the first study (called Study 04) and $39.7 \%$ vs $29.3 \%, \mathrm{p}=0.02$ for the second study (Study 05 ). In Study 04 , naloxegol $12.5 \mathrm{mg}$ was statistically significantly more effective than placebo with response rates of $40.8 \%$ vs $29.4 \%, p=0.02$. Pain scores were similar among all study groups and adverse events were most frequently reported in the naloxegol $25 \mathrm{mg}$ group. ${ }^{38}$

Two identical phase III double-blind, placebocontrolled studies evaluated 12.5 and $25 \mathrm{mg}$ doses of naloxegol in noncancer pain outpatients with OIC (4652 and 5700 patients, respectively). ${ }^{38}$ The primary endpoint of the 12-week study was $\geq 3$ SBMs a week and an increase of $\geq 1$ bowel movement per week over baseline for at least nine of the 12 weeks and for at least three of the final four weeks of the study. Response rates were significantly superior for naloxegol $25 \mathrm{mg}$ than placebo ( $44.4 \%$ vs $29.4 \%, p=0.001$ and $39.7 \%$ vs $29.3 \%, p=0.02$ for the two respective studies). A significant improvement over placebo was also observed for $12.5 \mathrm{mg}$ naloxegol in the first study ( $40.8 \%$ vs $29.4 \%, \mathrm{p}=0.02$ ). The time to first SBM after a dose and a higher average number of days in the week with $\geq 1 \mathrm{SBM}$ was superior in the group treated with $25 \mathrm{mg}$ naloxegol in both studies $(\mathrm{p}<0.001)$. Pain scores and daily dose of opioid analgesics were similar among all three study arms but adverse events were more frequently reported in the $25 \mathrm{mg}$ naloxegol group. ${ }^{38}$

Two randomized, double-blind, 12-week studies, KODIAC-04 and KODIAC-05, evaluated pain control in chronic noncancer pain patients with OIC treated with oral naloxegol 12.6 or $25 \mathrm{mg}$ or placebo daily. ${ }^{39}$ In KODIAC$04(\mathrm{n}=652)$, the mean pain score at baseline was 4.5 and changed over 12 weeks by $-0.2 \pm 1.07$ for naloxegol $12.5 \mathrm{mg},-0.3 \pm 0.87$ for naloxegol $25 \mathrm{mg}$ compared to $0.2 \pm 0.95$ for placebo (not significant). In KODIAC-05 $(\mathrm{n}=700)$, mean pain score at baseline was 4.6 and changed by $-0.1 \pm 0.94$ for naloxegol $12.5 \mathrm{mg},-0.1 \pm 0.87$ for naloxegol $25 \mathrm{mg}$, and $0.0 \pm 1.18$ for placebo (not significant) at 12 weeks. These studies suggest that opioid analgesia was maintained and not adversely affected over 12 weeks of naloxegol treatment. ${ }^{39}$ A 12-week extension of the KODIAC studies was published as the KODIAC-07 which compared daily doses of oral naloxegol 12.5 and $25 \mathrm{mg}$ to placebo with the primary endpoint being adverse events as well as pain scores, daily opioid dose, and quality of life metrics in chronic noncancer pain patients. The rate of adverse events was higher with $25 \mathrm{mg}$ oral naloxegol, as expected, compared to $12.5 \mathrm{mg}$ or placebo $(41.2 \%, 34.0 \%$, and $33.0 \%$, respectively) and the treatment-emergent adverse events occurring in more than $5 \%$ of patients in either naloxegol group were arthralgia (5.2\% of the $25 \mathrm{mg}$ naloxegol group) and diarrhea (5.3\% in the $12.5 \mathrm{mg}$ naloxegol group). ${ }^{40}$

\section{Long-Term Naloxegol Studies}

The long-term safety of naloxegol was evaluated in a 52week clinical study in noncancer pain patients taking 30 to 1000 morphine equivalents per day for at least four weeks. ${ }^{41}$ Patients were randomized to receive naloxegol $25 \mathrm{mg}$ per day or the usual care (investigator-determined laxative and/or bowel regimen). A total of 804 patients were included in the safety set with a mean duration of naloxegol exposure of 268 days (mean duration of usual care was 297 days). Adverse events occurred in $81.8 \%$ of the naloxegol and $72.2 \%$ of the usual-care study arms. The rate of side effects of naloxegol and usual care were $17.8 \%$ vs $3.3 \%$ for abdominal pain, $12.9 \%$ vs $5.9 \%$ for diarrhea, $9.4 \%$ vs $4.1 \%$ for nausea, $9.0 \%$ vs $4.8 \%$ for headache, $6.9 \%$ vs $1.1 \%$ for flatulence, and $5.1 \%$ vs $1.1 \%$ for pain in the upper abdominal region. Most of the adverse events occurring in the naloxegol group resolved upon naloxegol discontinuation. Two patients in each group had major adverse cardiovascular events (MACE) that were determined to be unrelated to the study drug. ${ }^{41}$

\section{Naloxegol Dosing and Pharmacokinetics}

An open-label, randomized study of naloxegol provided 42 healthy subjects with four single-dose treatments of naloxegol between 7-day washout periods. Subjects came to the study center the day before dosing and resided there for $48 \mathrm{hrs}$; fasting was required $10 \mathrm{hrs}$ before dosing and four hours afterward. Samples were taken over the next $72 \mathrm{hrs}$. The four treatment arms produced similar pharmacokinetic results. All patients were administered $25 \mathrm{mg}$ naloxegol which was given crushed, suspended in water, and taken 
orally; crushed, suspended in water and administered by nasogastric tube; mixed in $10 \mathrm{~mL}$ of an oral aqueous sweetened solution; and as an intact tablet taken orally. This study found that the tablet was bioequivalent to solutions and that dissolving the tablets in water or administering a solution by nasogastric tube did not reduce the rate or extent of naloxegol absorption. ${ }^{42}$

In a single ascending-dose study in healthy men, naloxegol exhibited linear pharmacokinetics up to doses of $1000 \mathrm{mg}$ with low to moderate pharmacokinetic variability among subjects. ${ }^{43}$ No sex differences were observed in a multiple ascending dose study which found doses up to $250 \mathrm{mg}$ every $12 \mathrm{hrs}$ were well tolerated. ${ }^{44}$ Because naloxegol relies on P-glucoprotein to maintain peripheral selectivity and is a substrate for the CYP3A enzyme system, drug-drug interactions must be considered, and it is contraindicated in patients taking drugs that greatly inhibit the CYP3A4 system. ${ }^{45}$ When naloxegol was administered concomitantly with quinidine in healthy volunteers taking $5 \mathrm{mg} / 70 \mathrm{~kg}$ intravenous morphine, it was found that the AUC of naloxegol and the $\mathrm{C}_{\max }$ increased, but it had no effect on morphine-induced miosis. ${ }^{46}$ Quinidine acts by inhibition of the CYP3A4 enzyme. This implied that the inhibition of P-glycoprotein (PGP), which is a substrate for the CYP3A enzyme, did not enhance the ability of naloxegol to penetrate the central nervous system. Neither quinidine nor placebo affected the pharmacokinetic properties of naloxegol, nor were the properties of morphine affected by the administration of naloxegol. ${ }^{46}$

A phase II double-blind, placebo-controlled, doseescalation study in 207 OIC patients taking a stable dose of 30 to 1000 morphine milligram equivalents for at least two weeks were randomized for a four-week treatment course with naloxegol 5,25 , or $50 \mathrm{mg}$ a day or placebo in sequential cohorts after a one-week placebo run-in. ${ }^{47}$ Patients receiving naloxegol 25 or $50 \mathrm{mg}$ a day had significantly superior results in the median change in the number of SBMs per week after one week of dosing compared to baseline (2.9 vs $1.0, \mathrm{p}=0.0020$ and 3.3 vs $0.5, p=0.0001$, respectively) and the increased rate of SBMs could be maintained over four weeks with naloxegol 25 and $50 \mathrm{mg}$. Pain was similar in both groups but adverse events were more frequently reported in the naloxegol groups and they were most frequent and had greater severity in the naloxegol $50 \mathrm{mg}$ group. $^{47}$

\section{Other Naloxegol Studies}

Opioid-induced bowel dysfunction may be caused in part by malfunction of the anal sphincter during defecation. In a double-blind crossover study of 24 healthy men, treatment was oral oxycodone $15 \mathrm{mg}$ twice a day combined with oral naloxegol $25 \mathrm{mg}$ once daily or placebo. ${ }^{48}$ Prior to the first dose and on the sixth day of this study, anal resting pressure and recto-anal inhibitory reflex (RAIR) were measured with manometry and rectal balloon distension. A probe was used to measure the functional lumen, that is, the distensibility of the anal canal. The use of naloxegol provided RAIR-induced sphincter relaxation of $15 \%(-45.9$ vs $-38.8 \mathrm{mmHg}, \mathrm{p}<0.01)$ but naloxegol was not different from placebo in terms of anal resting pressure and anal canal distensibility. ${ }^{48}$

\section{Other PAMORAs}

There are a number of possible OIC treatments that are not addressed in this review. For example, few PAMORAs have been developed but are not commercially available today. A product related to naltrexone, $6 \beta$-naltrexol was explored as a PAMORA for OIC but never commercially developed. ${ }^{49}$ Alvimopan, a PAMORA that was approved for accelerating upper and lower gastrointestinal tract recovery following partial bowel resection with primary anastomosis, never sought regulatory approval for treatment of OIC. ${ }^{50}$ Alvimopan is an oral agent indicated for the short-term treatment of postoperative ileus in hospitalized patients. ${ }^{45}$ However, alvimopan had been studied in chronic noncancer pain patients with OIC. In one randomized placebo-controlled study, 485 patients were randomized to 0.5 alvimopan once or twice daily for 12 weeks. Response rate, defined as patients with $\geq 3$ SBMs a week and $\geq 1$ more SBM a week over baseline, were similar between groups ( $63 \%$ for both alvimopan groups vs $56 \%$ placebo $).^{50}$ In a similar placebo-controlled study $(n=518)$ of noncancer pain patients, the $0.5 \mathrm{mg}$ alvimopan twicedaily group had significantly higher responder rates than the placebo group ( $72 \%$ vs $48 \%, \mathrm{p}<0.001)$ and alvimopan was well tolerated. ${ }^{51}$

\section{Clinical Considerations}

The clinical efficacy of methylnaltrexone, naldemedine, and naloxegol are well established in a variety of clinical trials. However, there remain some important safety points to consider and clinical considerations for prescribers. 


\section{Cardiovascular Safety}

The possible association between PAMORAs and cardiovascular adverse events remains to be elucidated. An increase in myocardial infarction has been observed in studies where patients took alvimopan twice daily. ${ }^{52}$ Alvimopan has been associated with an increased risk for myocardial infarction when used long term; it is indicated for postoperative ileus for hospital inpatients rather than chronic use and it is not indicated for OIC. ${ }^{45}$ However, the postulated mechanism of action may be of general interest for OICs. It has been suggested that the antagonism at the $\mu$-opioid receptors may work against the contraction of smooth muscles caused by opioids. ${ }^{53,54}$ This effect of smooth-muscle relaxation occurs in the gastrointestinal tract, but it is possible it might occur in the smooth muscle of the heart.

In a long-term study of daily methylnaltrexone $12 \mathrm{mg}$ in 1034 chronic noncancer pain patients, nine patients experienced a serious cardiac-related adverse event $(<1 \%)$; all of these instances occurred in patients who had prior cardiovascular risk factors. ${ }^{22}$ A post hoc study of these events by a blinded external committee adjudicated 3/7 of the events to be major adverse cardiac events (MACE). In addition, 5/ 1034 patients discontinued the study because of prolongation of the QT interval deemed to be caused by methylnaltrexone; in all five cases, the QT interval returned to normal values once the study drug was discontinued. ${ }^{22}$

Naloxegol has also been implicated for possibly prolongation of the QT interval, which can elevate the risk for a potentially life-threatening arrhythmia, typically polymorphic ventricular tachycardia. ${ }^{55}$ A positive- and placebo-controlled single-dose study in 52 healthy adult men evaluated therapeutic naloxegol $(25 \mathrm{mg})$, supratherapeutic naloxegol (150 mg), moxifloxacin $400 \mathrm{mg}$ (positive control) and placebo in the Williams Latin Square Design ( 1 in 4 sequences) with a washout period between doses of at least five days. The QT intervals of subjects were evaluated by digital 12-lead ECG at baseline and at 10 points over the $24 \mathrm{hr}$ post-dosing period for each of the four doses. The mean increases in the QT interval for both naloxegol doses were $<5$ milliseconds at each time point and it was determined that naloxegol had no clinically meaningful effect on the QT duration. ${ }^{55}$

However, it must be considered that PAMORAs are by definition administered to patients with cancer or chronic noncancer pain, which are often associated with comorbidities such as cardiovascular risk factors. In an analysis of four phase III clinical studies of naloxegol 12.5 or $25 \mathrm{mg}$ in noncancer pain patients $(n=2135)$ it was found that $68 \%$ of patients had at least one risk factor for cardiovascular disease and $41 \%$ had a history of cardiovascular disease or diabetes. ${ }^{56}$ Over the course of these studies, there were no increases reported in blood pressure, heart rate, or ratepressure product. The rate of MACE per 100 patient-years of exposure was 1.13 (95\% confidence interval 0.31 to $2.89)$ for placebo compared to 0.75 (95\% confidence interval, 0.24-1.75) for naloxegol at all doses across all studies. The relative risk of MACE for naloxegol versus placebo or usual care was 0.67 (95\% confidence interval, 0.14 to 3.36 ). No clinically meaningful changes in the ECG were observed in naloxegol or placebo patients. Among patients with pre-existing cardiovascular disease, two or more risk factors for cardiovascular disease, or pre-existing diabetes, there was a higher proportion of adverse cardiovascular events but these proportions were similar in the naloxegol and placebo/usual care groups. ${ }^{56}$ In a 12-week extension study of oral naloxegol 12.5 and $25 \mathrm{mg}$ versus placebo (KODIAC-07), one major cardiovascular adverse event occurred in a patient in the $12.5 \mathrm{mg}$ naloxegol group but it was deemed unrelated to the study drug. ${ }^{40}$

Thus, the cardiovascular risk factors do not seem to present a major clinical consideration at this point although further investigation is warranted.

\section{Cancer}

Historically, opioids have been implicated in the promotion or prevention of tumors and metastases but with inconclusive findings. ${ }^{57}$ Considerable interest and ongoing research is attempting to sort through this question. The $\mu$-opioid receptor has recently been identified as a plausible target for anticancer drug development based on cellular, molecular, animal, and human studies. ${ }^{58}$ It had been observed in retrospective studies that opioids seemed to promote tumor growth and had an adverse effect on patients with advanced forms of cancer. ${ }^{58}$ In a study of Lewis lung carcinoma (LLC) tumorigenicity in cells and animal models; $\mu$ receptor agonists (morphine) increased LLC cell growth in vitro, while silencing expression of the $\mu$-opioid receptors inhibited invasion of LLC growth by $50 \%$ to $80 \%$. ${ }^{59}$ When $\mu$-opioid-receptor knockout mice were injected with LLC, they did not develop significant tumors, in contrast to wildtype controls. ${ }^{59}$ It is not clear what role, if any, PAMORAs might play in such processes.

Morphine has a number of effects that are not mediated by opioid receptors. For example, morphine alters the 
circulating proteolytic profile in mice with and without tumors and it can downregulate the pro-invasive and proangiogenic interaction of breast cancer cells and macrophages in vitro. ${ }^{60,61}$ In addition, the toll-like receptor 4 (TLR4) receptors in the body are responsive to opioids such that certain opioids and/or their metabolites may activate TLR4 cells which are expressed in cancer cells and tumor-associated cells; furthermore, TLR4 cells help to regulate the signaling pathways on which metastasis depends. ${ }^{62-66}$ This action is complicated by the fact that while opioids may activate TLR4, they may also prevent lipopolysaccharide-induced activation of TLR $4 .{ }^{63} \mathrm{~A}$ recent human study demonstrated the ability of opioids to modulate TLR4 in a clinical setting. ${ }^{67}$ This is an early study and results remain unclear, for instance it is not known if all opioids modulate TLR4 to the same degree nor what the clinical consequences of TLR4 modulation, if any, might exert on tumor cells. The overexpression of $\mu$ opioid receptors in human non-small-cell lung cancer (NSCLC) was shown to increase tumor growth and metastasis but the mechanism had been unclear. It may be that the $\mu$-opioid receptor regulates growth factor receptor signaling and epithelial mesenchymal transition (EMT) in NSCLC cells in humans. ${ }^{66}$

Methylnaltrexone has been studied as a possible agent to slow cancer progression. ${ }^{58}$ Utilizing pooled data from two randomized, placebo-controlled studies (one phase III and one phase IV) enrolling advanced end-stage cancer patients with OIC, subcutaneous methylnaltrexone or placebo was administered in a double-blind phase followed by an open-label phase in which all patients were treated with subcutaneous methylnaltrexone. ${ }^{68}$ The study enrolled patients with various types of cancer and was carried out as an ad hoc post-study analysis. Patients treated with methylnaltrexone $(\mathrm{n}=117)$ had a longer median overall survival time of 76 days $(95 \%$ confidence interval, 43-109) compared to 56 days ( $95 \%$ confidence interval, 43-69) in the 112 placebo patients; this difference achieved statistical significance, $\mathrm{p}=0.033$. Of the patients considered to be methylnaltrexone responders, overall survival was even more pronounced, 118 versus 56 days, $\mathrm{p}<0.001$. Though intriguing, this study must be put into context. Being an unplanned post-hoc data analysis that was not designed to measure survival times, it has limitations. The design of this study is such that there is a risk of selection bias, plus it was a relatively short study. In fact, the prolonged survival times in methylnaltrexone patients might be explained in any of several ways. For example, methylnaltrexone improved gastrointestinal health which may have extended longevity; it is also possible that methylnaltrexone itself had a direct impact on the tumor. ${ }^{68}$

\section{Contraindications and Prescribing Considerations}

Predictive factors for PAMORA response and "overresponse" (diarrhea) are not known. ${ }^{69}$ It is not clear if PAMORAs have different effects depending on the type of opioid the patient is taking, but there is some limited evidence that methadone may inhibit the mechanism of action of lubiprostone ${ }^{70}$ and there is a higher rate of adverse events when methadone patients use naloxegol. ${ }^{69}$

Known or suspected gastrointestinal obstruction or the risk of recurrence for a past obstruction contraindicate the use of PAMORAs because of the risk for gastrointestinal perforation. ${ }^{69}$ Opioid withdrawal symptoms are of concern when using PAMORAs as they are opioid antagonists being used in patients who are likely opioid dependent. A few such cases have been observed in various studies, but they are rare. For example, in COMPOSE-1 and COMPOSE- 2 studies of naldemedine, $<1 \%$ of both naldemedine and placebo patients experienced symptoms that were deemed possibly related to opioid withdrawal. ${ }^{71}$

None of the studies in this narrative review demonstrated a compromise or loss of analgesia as a result of PAMORA use.

\section{Pediatric Patients}

Opioids are often used in pediatric oncology patients to manage pain, ${ }^{72}$ and about half of them will develop OIC or other forms of bowel dysfunction. ${ }^{73}$ Although there are guidelines for the treatment of pediatric constipation, ${ }^{74}$ there is no specific guidance for OIC. None of the PAMORA agents are indicated for pediatric use, and there is a paucity of literature on the use of PAMORAs in pediatric patients. ${ }^{72}$ A retrospective study of methylnaltrexone was conducted in pediatric oncology patients $(n=15$, median age 14 years, 4 to 17), two of whom were in palliative care. ${ }^{72}$ All patients were receiving opioids for a median of 10 days prior to the first dose of methylnaltrexone (median oral morphine dose equivalent was $5.7 \mathrm{mg} /$ $\mathrm{kg} /$ day, range 1.5 to $29.2 \mathrm{mg} / \mathrm{kg} /$ day). No bowel movement had occurred in four or more days in 14/15 patients and one patient suffered fecal impaction. The mean dose of subcutaneous methylnaltrexone was $0.15 \pm 0.02 \mathrm{mg} / \mathrm{kg} / \mathrm{dose}$ (range $3-12 \mathrm{mg} / \mathrm{kg} /$ day) and $10 / 15$ patients had a bowel movement within 30 mins of injection and four other 
patients had a bowel movement within four hours. ${ }^{72}$ The injection of subcutaneous methylnaltrexone was administered to these cancer patients as rescue therapy rather than maintenance therapy. The response rate to methylnaltrexone was higher in these pediatric patients ${ }^{72}$ than in adults $(74 \%$ vs $50 \%$ reported in studies of adult cancer patients ${ }^{17,75,76}$ ). The optimal dose for pediatric oncology patients or any pediatric patient is not known. ${ }^{72}$

\section{Pregnant and Lactating Patients}

There are scarce data relating to the use of PAMORAs in pregnant and lactating women. A pregnant patient on opioid therapy administered a PAMORA may cause the fetus to experience opioid withdrawal. ${ }^{71}$ There is little guidance about the use of PAMORAs or opioids in this population and the clinician must make evaluate with the patient whether benefits exceed the potential risks.

\section{Costs}

No PAMORA product is available in generic formulation. There are no head to head studies comparing PAMORAs so clinicians must make prescribing choices based on patient preference, drug availability, and price. See Table 3.

\section{Discussion}

There are three main PAMORAs on the market (methylnaltrexone, naloxegol, naldemedine) for the treatment of OIC and numerous clinical studies support their safety and efficacy. The effects of PAMORAs appear to be durable over time although most of the long-term studies of PAMORAs have been on safety rather than efficacy. While these agents are effective, not all patients are "responders" and there are not clear stratification systems to determine responders, non-responders, and over-responders. Further, there are no comparative data among products. Clinicians must select the product they deem most appropriate. If a patient does not respond to a given PAMORA,

Table 3 The Average Retail Prices in the United States for a 30Day Course of PAMORAs; Note That Discounting, Certain Insurance Plans, and Coupons May Be Available and Would Lower These Prices

\begin{tabular}{|l|l|}
\hline Drug and Dose & $\begin{array}{l}\text { Average Retail } \\
\text { Price }\end{array}$ \\
\hline $\begin{array}{l}\text { Methylnaltrexone, oral, } 450 \mathrm{mg} / \text { day (3 tablets of } \\
150 \mathrm{mg} \text { each) }\end{array}$ & $\sim \$ 2074$ \\
\hline Naloxegol $25 \mathrm{mg}$, oral, once-daily & $\$ 448$ \\
\hline Naldemedine $0.2 \mathrm{mg}$, oral, once-daily & $\$ 408$ \\
\hline
\end{tabular}

Note: Data from GoodRx. ${ }^{77}$ it may be helpful to rotate to a different PAMORA although there are no guidelines or clinical trials to support this strategy.

There are important distinctions among these PAMORAs. Methylnaltrexone bromide is the oldest of these agents and was available initially only for subcutaneous injection. Its rapid onset of action and formulation made it a drug that was primarily used for rescue although it can be used on a daily basis. A new oral formulation of methylnaltrexone may make it more practical for outpatient used. It is typically prescribed for as-needed dosing in patients both on short-term and longterm opioid therapy.

Naldemedine and naloxegol are available as oral tablets to be taken once a day. Both are metabolized via the CYP3A4 enzyme system, making potential pharmacokinetic drug-drug interactions possible. Patients taking drugs, supplements, or eating foods associated with CYP3A4 inhibition may experience a potentiation of effect or drug-drug interactions.

Naloxegol is available as an oral tablet but it may be taken crushed in water by mouth or via a nasogastric tube in patients with dysphagia. Naldemedine is the newest PAMORA and its labeling lists a side effect of tears in the stomach or perforation of the intestinal wall, which would necessitate emergency medical intervention.

\section{Conclusions}

OIC is a distressing and sometimes treatment-limiting side effect of opioid therapy. PAMORAs work by antagonizing enteric $\mu$-opioid receptors, thus blunting the opioid-associated effects on the GI system, without crossing the blood-brain barrier so that central analgesia is not affected. The three main PAMORAs available are methylnaltrexone (subcutaneous and oral formulation), nalmedine, and naloxegol. Clinical studies demonstrate that these agents are effective in improving gastrointestinal health and relieving OIC, although they are associated with adverse effects most of which are deemed to be mild to moderate. For patients with OIC, PAMORAs may be safe, effective, and well-tolerated agents to help relieve OIC.

\section{Abbreviations}

CYP, cytochrome P; EMT, epithelial mesenchymal transition; $\geq$ OIC, opioid-induced constipation; kg, kilogram; LLC, Lewis lung carcinoma; MACE, major adverse cardiovascular event; mg, milligram; NSCLC, non-small-cell lung cancerPAMORA, peripherally acting $\mu$-opioid receptor; PACSYM, Patient Assessment of Constipation Symptoms; PRN, as needed; RFBM, rescue-free bowel movement; SBM, spontaneous bowel movement; TLR4, toll-like receptor 4. 


\section{Acknowledgments}

There was no funding provided by a sponsor or other agency to produce this paper or in support of this work.

\section{Disclosure}

JVP $\mathrm{Jr}$ is a consultant/speaker or researcher for AstraZeneca, US World Meds, BDSI, Salix, Enalare, Scilex, and Neumentum and is a principal at Native Cardio. He also reports personal fees from BDSI, during the conduct of the study; grants and/or personal fees from Salix and Astra Zeneca, outside the submitted work. PJC is on the advisory board of GlaxoSmithKline, Consumer Healthcare and is a consultant for Daichii Sankyo. He also reports personal fees from GlaxoSmithKline, Daiichi Sankyo, and BTG, assisted in media work for Algiatry, outside the submitted work. PM has received speaker fees or grants from Abbott, Alylam, Bayer, AstraZeneca, BMS, Boeringer-Ingelheim, Internetmedicine AB, Lilly, Novo Nordsik, Octupus Medical, Orion Pharma, Pfizer and Vifor Pharma. The authors report no other conflicts of interest in this work.

\section{References}

1. Camilleri M. Opioid-induced constipation: challenges and therapeutic opportunities. Am J Gastroenterol. 2011;106(5):835-842; quiz 843. doi:10.1038/ajg.2011.30

2. Bell TJ, Panchal SJ, Miaskowski C, Bolge SC, Milanova T, Williamson R. The prevalence, severity, and impact of opioid-induced bowel dysfunction: results of a US and European Patient Survey (PROBE 1). Pain Medicine (Malden, Mass). 2009;10(1):35-42. doi:10.1111/j.1526-4637.2008.00495.x

3. Diego L, Atayee R, Helmons P, Hsiao G, von Gunten CF. Novel opioid antagonists for opioid-induced bowel dysfunction. Expert Opin Investig Drugs. 2011;20(8):1047-1056. doi:10.1517/13543784.2011.592830

4. Pappagallo M. Incidence, prevalence, and management of opioid bowel dysfunction. Am J Surg. 2001;182(5ASuppl):11s-18s. doi:10.1016/S0002-9610(01)00782-6

5. Panchal SJ, Muller-Schwefe P, Wurzelmann JI. Opioid-induced bowel dysfunction: prevalence, pathophysiology and burden. Int J Clin Pract. 2007;61(7):1181-1187. doi:10.1111/ijcp.2007.61.issue-7

6. Kalso E, Edwards JE, Moore RA, McQuay HJ. Opioids in chronic non-cancer pain: systematic review of efficacy and safety. Pain. 2004;112(3):372-380. doi:10.1016/j.pain.2004.09.019

7. Tuteja AK, Biskupiak J, Stoddard GJ, Lipman AG. Opioid-induced bowel disorders and narcotic bowel syndrome in patients with chronic non-cancer pain. Neurogastroenterol Motil. 2010;22(4):424 430, e496. doi:10.1111/nmo.2010.22.issue-4

8. LoCasale RJ, Datto C, Wilson H, Yeomans K, Coyne KS. The burden of opioid-induced constipation: discordance between patient and health care provider reports. J Manag Care Spec Pharm. 2016;22 (3):236-245. doi:10.18553/jmcp.2016.22.3.236

9. Ahmedzai SH, Boland JW. Constipation: opioid antagonists in people prescribed opioids. BMJ Clin Evid. 2015;2015:2407.

10. Lipman AG, Karver S, Austin CG, Stambler N, Israel RJ. Methylnaltrexone for opioid-induced constipation in patients with advanced illness: a 3-month open-label treatment extension study. J Pain Palliat Care Pharmacother. 2011;25(2):136-145.
11. Drugs.com. Methylnaltrexone (oral/injection). Drugs.com. Available from: https://www.drugs.com/mtm/methylnaltrexone-oral-injection. html. 2019. Accessed October 24, 2019 ..

12. MPR. Movantik no longer controlled substance, DEA rules. MPR, The Right Dose of Information. Available from: https://www.empr. com/home/news/movantik-no-longer-controlled-substance-dea-rules/. Published 2015. Accessed October 24, 2019.

13. Bull J, Wellman CV, Israel RJ, Barrett AC, Paterson C, Forbes WP. Fixed-dose subcutaneous methylnaltrexone in patients with advanced illness and opioid-induced constipation: results of a randomized, placebo-controlled study and open-label extension. J Palliat Med. 2015;18(7):593-600. doi:10.1089/jpm.2014.0362

14. Zacny JP, Wroblewski K, Coalson DW. Methylnaltrexone: its pharmacological effects alone and effects on morphine in healthy volunteers. Psychopharmacology. 2015;232(1):63-73. doi:10.1007/ s00213-014-3637-8

15. Mori M, Ji Y, Kumar S, Ashikaga T, Ades S. Phase II trial of subcutaneous methylnaltrexone in the treatment of severe opioid-induced constipation (OIC) in cancer patients: an exploratory study. Int J Clin Oncol. 2017;22(2):397-404. doi:10.1007/s10147-016-1041-6

16. Chamberlain BH, Cross K, Winston JL, et al. Methylnaltrexone treatment of opioid-induced constipation in patients with advanced illness. J Pain Symptom Manage. 2009;38(5):683-690. doi:10.1016/j. jpainsymman.2009.02.234

17. Thomas J, Karver S, Cooney GA, et al. Methylnaltrexone for opioid-induced constipation in advanced illness. $N$ Engl J Med. 2008;358(22):2332-2343. doi:10.1056/NEJMoa0707377

18. Viscusi ER, Barrett AC, Paterson C, Forbes WP. Efficacy and safety of methylnaltrexone for opioid-induced constipation in patients with chronic noncancer pain: a placebo crossover analysis. Reg Anesth Pain Med. 2016;41(1):93-98. doi:10.1097/AAP.0000000000000341

19. Michna E, Watier A, Schulman S, et al. 728 Subcutaneous methylnaltrexone for the treatment of opioid-induced constipation in patients with chronic non-malignant pain. Eur J Pain. 2009;13:S210-S210.

20. Michna E, Weil AJ, Duerden M, et al. Efficacy of subcutaneous methylnaltrexone in the treatment of opioid-induced constipation: a responder post hoc analysis. Pain Medicine (Malden, Mass). 2011;12(8):1223-1230. doi:10.1111/j.1526-4637.2011.01189.x

21. Anissian L, Schwartz HW, Vincent K, et al. Subcutaneous methylnaltrexone for treatment of acute opioid-induced constipation: Phase 2 study in rehabilitation after orthopedic surgery. $J$ Hosp Med. 2012;7(2):67-72.

22. Webster LR, Michna E, Khan A, Israel RJ, Harper JR. Long-term safety and efficacy of subcutaneous methylnaltrexone in patients with opioid-induced constipation and chronic noncancer pain: a Phase 3, open-label trial. Pain Medicine (Malden, Mass). 2017;18(8):1496-1504. doi:10.1093/pm/pnx148

23. Rauck R, Slatkin NE, Stambler N, Harper JR, Israel RJ. Randomized, double-blind trial of oral methylnaltrexone for the treatment of opioid-induced constipation in patients with chronic noncancer pain. Pain Pract. 2017;17(6):820-828. doi:10.1111/papr.12535

24. Nalamachu SR, Pergolizzi J, Taylor R, et al. Efficacy and tolerability of subcutaneous methylnaltrexone in patients with advanced illness and opioid-induced constipation: a responder analysis of 2 randomized, placebo-controlled trials. Pain Pract. 2015;15 (6):564-571

25. Slatkin NE, Lynn R, Su C, Wang W, Israel RJ. Characterization of abdominal pain during methylnaltrexone treatment of opioid-induced constipation in advanced illness: a post hoc analysis of two clinical trials. J Pain Symptom Manage. 2011;42(5):754-760. doi:10.1016/j. jpainsymman.2011.02.015

26. Mehta N, O’Connell K, Giambrone GP, Baqai A, Diwan S. Efficacy of methylnaltrexone for the treatment of opiod-induced constipation: a meta-analysis and systematic review. Postgrad Med. 2016;128 (3):282-289. doi:10.1080/00325481.2016.1149017 
27. Hale M, Wild J, Reddy J, Yamada T, Arjona Ferreira JC. Naldemedine versus placebo for opioid-induced constipation (COMPOSE-1 and COMPOSE-2): two multicentre, phase 3, double-blind, randomised, parallel-group trials. Lancet Gastroenterol Hepatol. 2017;2(8):555-564. doi:10.1016/S2468-1253(17)30105-X

28. Katakami N, Harada T, Murata T, et al. Randomized Phase III and extension studies of naldemedine in patients with opioid-induced constipation and cancer. J Clin Oncol. 2017;35(34):3859-3866. doi:10.1200/JCO.2017.73.0853

29. Saito Y, Yokota T, Arai M, Tada Y, Sumitani M. Naldemedine in Japanese patients with opioid-induced constipation and chronic noncancer pain: open-label Phase III studies. J Pain Res. 2019;12:127-138. doi:10.2147/JPR.S175900

30. Webster LR, Nalamachu S, Morlion B, et al. Long-term use of naldemedine in the treatment of opioid-induced constipation in patients with chronic noncancer pain: a randomized, double-blind, placebo-controlled phase 3 study. Pain. 2018;159(5):987-994. doi:10.1097/j.pain.0000000000001174

31. Esmadi M, Ahmad D, Hewlett A. Efficacy of naldemedine for the treatment of opioid-induced constipation: a meta-analysis. J Gastrointest Liver Dis. 2019;28(1):41-46. doi:10.15403/jgld.2014.1121.281.any

32. Fukumura K, Yokota T, Baba Y, Arjona Ferreira JC. Phase 1, randomized, double-blind, placebo-controlled studies on the safety, tolerability, and pharmacokinetics of naldemedine in healthy volunteers. Clin Pharmacol Drug Dev. 2018;7(5):474 483. doi:10.1002/cpdd.v7.5

33. Katakami N, Oda K, Tauchi K, et al. Phase IIb, randomized, double-blind, placebo-controlled study of naldemedine for the treatment of opioid-induced constipation in patients with cancer. $J$ Clin Oncol. 2017;35(17):1921-1928. doi:10.1200/JCO.2016.70.8453

34. Webster LR, Yamada T, Arjona Ferreira JC, Phase A. 2b, randomized, double-blind placebo-controlled study to evaluate the efficacy and safety of naldemedine for the treatment of opioid-induced constipation in patients with chronic noncancer pain. Pain Medicine (Malden, Mass). 2017;18(12):2350-2360. doi:10.1093/pm/pnw325

35. Garnock-Jones KP. Naloxegol: a review of its use in patients with opioid-induced constipation. Drugs. 2015;75(4):419-425. doi:10.1007/ s40265-015-0357-2

36. Bui K, Zhou D, Xu H, Floettmann E, Al-Huniti N. Clinical pharmacokinetics and pharmacodynamics of naloxegol, a peripherally acting $\mu$-opioid receptor antagonist. Clin Pharmacokinet. 2017;56 (6):573-582. doi:10.1007/s40262-016-0479-z

37. vonRoenn J, Tack J, Barker P, Lowe E, Flesichmann C, Sostek M. Challenges in Patient Recruitment During KODIAC-06, a Randomized Placebo-Controlled, Double-Blind, Multicenter, phase 3 Trial of Naloxegol in Patients with Neoplasia and Opioid-Induced Constipation (OIC). Berlin, Germany: MASCC/ISOO International Symposium on Supportive Care in Cancer; 2013.

38. Chey WD, Webster L, Sostek M, Lappalainen J, Barker PN, Tack J. Naloxegol for opioid-induced constipation in patients with noncancer pain. $N$ Engl $J$ Med. 2014;370(25):2387-2396. doi:10.1056/NEJM oa1310246

39. Webster L, Diva U, Tummala R, Sostek M. Treatment with naloxegol versus placebo: pain assessment in patients with noncancer pain and opioid-induced constipation. Pain Pract. 2018;18(4):505-514. doi:10.1111/papr.2018.18.issue-4

40. Webster L, Tummala R, Diva U, Lappalainen J. A 12-week extension study to assess the safety and tolerability of naloxegol in patients with noncancer pain and opioid-induced constipation. $J$ Opioid Manag. 2016;12(6):405-419. doi:10.5055/jom.2016.0360

41. Webster L, Chey WD, Tack J, Lappalainen J, Diva U, Sostek M. Randomised clinical trial: the long-term safety and tolerability of naloxegol in patients with pain and opioid-induced constipation. Aliment Pharmacol Ther. 2014;40(7):771-779. doi:10.1111/apt.2014.40.issue-7
42. Bui K, Birmingham B, Diva U, Berger B. An open-label, randomized bioavailability study of alternative methods of oral administration of naloxegol in healthy subjects. Clin Pharmacol Drug Dev. 2017;6 (4):420-427. doi:10.1002/cpdd. 335

43. Eldon MA, Kugler AR, Medve RA, Bui K, Butler K, Sostek M. Safety, tolerability, pharmacokinetics, and pharmacodynamic effects of naloxegol at peripheral and central nervous system receptors in healthy male subjects: A single ascending-dose study. Clin Pharmacol Drug Devel. 2015;4(6):434-441. doi:10.1002/cpdd.206

44. Eldon MA, Kugler AR, Medve RA, Bui K, Butler K, Sostek M. Safety, tolerability, and pharmacokinetics of multiple ascending doses of naloxegol. Clin Pharmacol Drug Devel. 2015;4(6):442-448. doi: $10.1002 /$ cpdd. 204

45. Bowers BL, Crannage AJ. The evolving role of long-term pharmacotherapy for opioid-induced constipation in patients being treated for noncancer pain. $J$ Pharm Pract. 2019;32(5):558-567.

46. Bui K, She F, Zhou D, Butler K, Al-Huniti N, Sostek M. The effect of quinidine, a strong P-glycoprotein inhibitor, on the pharmacokinetics and central nervous system distribution of naloxegol. J Clin Pharmacol. 2016;56(4):497-505. doi:10.1002/jcph.v56.4

47. Webster L, Dhar S, Eldon M, Masuoka L, Lappalainen J, Sostek M. A phase 2, double-blind, randomized, placebo-controlled, doseescalation study to evaluate the efficacy, safety, and tolerability of naloxegol in patients with opioid-induced constipation. Pain. 2013;154 (9):1542-1550. doi:10.1016/j.pain.2013.04.024

48. Gronlund D, Poulsen JL, Krogh K, et al. The impact of naloxegol on anal sphincter function - Using a human experimental model of opioid-induced bowel dysfunction. Eur $J$ Pharm Sci. 2018;117:187-192. doi:10.1016/j.ejps.2018.02.008

49. Yancey-Wrona J, Dallaire B, Bilsky E, et al. 6[beta]-naltrexol, a peripherally selective opioid antagonist that inhibits morphine-induced slowing of gastrointestinal transit: an exploratory study. Pain Med. 2011;12(12):1727-1737.

50. Irving G, Penzes J, Ramjattan B, et al. A randomized, placebo-controlled phase 3 trial (Study SB-767905/013) of alvimopan for opioid-induced bowel dysfunction in patients with non-cancer pain. J Pain. 2011;12 (2):175-184. doi:10.1016/j.jpain.2010.06.013

51. Jansen JP, Lorch D, Langan J, et al. A randomized, placebo-controlled phase 3 trial (Study SB-767905/012) of alvimopan for opioid-induced bowel dysfunction in patients with non-cancer pain. J Pain. 2011;12 (2):185-193. doi:10.1016/j.jpain.2010.06.012

52. Brenner D, Chey WD. An evidence-based review of novel and emerging therapies for constipation in patients taking opioid analgesics. $\mathrm{Am}$ J Gastroenterol. 2014;2:38-46. doi:10.1038/ajgsup.2014.8

53. Wood J, Galligan J. Function of opioids in the enteric nervous system. Neurogastroenterol Motil. 2004;16:17-28. doi:10.1111/ nmo.2004.16.issue-s2

54. Yuan C, Foss J. J M. Effects of methylnaltrexone on morphine-induced inhibition of contraction in isolated guinea-pig ileum and human intestine. Eur J Pharmacol. 1995;276:107-111. doi:10.1016/0014-2999(95) 00018-G

55. Gottfridsson C, Carlson G, Lappalainen J, Sostek M. Evaluation of the effect of Naloxegol on cardiac repolarization: a randomized, placebo- and positive-controlled crossover thorough QT/QTc study in healthy volunteers. Clin Ther. 2013;35(12):1876-1883. doi:10.1016/j.clinthera. 2013.09.019

56. White WB, Kowey P, Diva U, Sostek M, Tummala R. Cardiovascular safety of the selective mu-opioid receptor antagonist naloxegol: a novel therapy for opioid-induced constipation. $J$ Cardiovasc Pharmacol Ther. 2018;23(4):309-317. doi:10.1177/1074248418760239

57. Afsharimani B, Doornebal CW, Cabot PJ, Hollmann MW, Parat MO. Comparison and analysis of the animal models used to study the effect of morphine on tumour growth and metastasis. $\mathrm{Br}$ J Pharmacol. 2015;172(2):251-259. doi:10.1111/bph.12589 
58. Singleton PA, Moss J, Karp DD, Atkins JT, Janku F. The mu opioid receptor: a new target for cancer therapy? Cancer. 2015;121 (16):2681-2688. doi:10.1002/cncr.v121.16

59. Mathew EB, Lennon MF, Siegler JJ, et al. The novel role of the Mu opioid receptor in lung cancer progression: a laboratory investigation. Anesthesia Analgesia. 2011;112(3):558-567.

60. Khabbazi S, Goumon Y, Parat MO. Morphine modulates interleukin-4- or breast cancer cell-induced pro-metastatic activation of macrophages. Sci Rep. 2015;5:11389. doi:10.1038/srep11389

61. Khabbazi S, Nassar ZD, Goumon Y, Parat MO. Morphine decreases the pro-angiogenic interaction between breast cancer cells and macrophages in vitro. Sci Rep. 2016;6:31572. doi:10.1038/srep31572

62. Hutchinson MR, Zhang Y, Shridhar M, et al. Evidence that opioids may have toll-like receptor 4 and MD-2 effects. Brain Behav Immun. 2010;24(1):83-95. doi:10.1016/j.bbi.2009.08.004

63. Xie N, Gomes FP, Deora V, et al. Activation of mu-opioid receptor and Toll-like receptor 4 by plasma from morphine-treated mice. Brain Behav Immun. 2017;61:244-258. doi:10.1016/j.bbi.2016.12.002

64. Liao SJ, Zhou YH, Yuan Y, et al. Triggering of Toll-like receptor 4 on metastatic breast cancer cells promotes alphavbeta3-mediated adhesion and invasive migration. Breast Cancer Res Treat. 2012;133 (3):853-863. doi:10.1007/s10549-011-1844-0

65. Ikebe M, Kitaura Y, Nakamura M, et al. Lipopolysaccharide (LPS) increases the invasive ability of pancreatic cancer cells through the TLR4/MyD88 signaling pathway. J Surg Oncol. 2009;100 (8):725-731. doi:10.1002/(ISSN)1096-9098

66. Lennon FE, Mirzapoiazova T, Mambetsariev B, et al. The Mu opioid receptor promotes opioid and growth factor-induced proliferation, migration and Epithelial Mesenchymal Transition (EMT) in human lung cancer. PLoS One. 2014;9(3):e91577. doi:10.1371/journal.pone.0091577

67. Xie N, Matigian N, Vithanage T, et al. Effect of perioperative opioids on cancer-relevant circulating parameters: $\mathrm{Mu}$ opioid receptor and toll-like receptor 4 activation potential, and proteolytic profile. Clin Cancer Res. 2018;24:2319-2327. doi:10.1158/1078-0432.CCR-18-0172

68. Janku F, Johnson LK, Karp DD, Atkins JT, Singleton PA, Moss J. Treatment with methylnaltrexone is associated with increased survival in patients with advanced cancer. Ann Oncol. 2016;27 (11):2032-2038. doi:10.1093/annonc/mdw317
69. Viscusi ER. Clinical overview and considerations for the management of opioid-induced constipation in patients with chronic noncancer pain. Clin J Pain. 2019;35(2):174-188. doi:10.1097/AJP.0000000000000662

70. Cuppoletti J, Chakrabarti J, Tewari K, Malinowska DH. Methadone but not morphine inhibits lubiprostone-stimulated Cl- currents in T84 intestinal cells and recombinant human $\mathrm{ClC}-2$, but not $\mathrm{CFTR} \mathrm{Cl-}$ currents. Cell Biochem Biophys. 2013;66(1):53-63. doi:10.1007/ s12013-012-9406-6

71. $\mathrm{Hu} \mathrm{K}$, Bridgeman MB. Naldemedine (Symproic) for the treatment of opioid-induced constipation. P T. 2018;43(10):601-627.

72. Rodrigues A, Wong C, Mattiussi A, Alexander S, Lau E, Dupuis LL. Methylnaltrexone for opioid-induced constipation in pediatric oncology patients. Pediatr Blood Cancer. 2013;60(10):1667-1670. doi:10.1002/ pbc.v60.10

73. Woolery M, Carroll E, Fenn E, et al. A constipation assessment scale for use in pediatric oncology. J Pediatr Oncol Nurs. 2006;23 (2):65-74. doi:10.1177/1043454205285874

74. Baker SS, Liptak GS, Colletti RBet al,. Clinical Practice Guideline: evaluation and treament of constipation in infants and children: recommendations of the North American society for pediatric gastroenterology, hepatology and nutrition. J Pediatric Gastroenterol Nutri. 2006;43:e1-e13. doi:10.1097/01.mpg.0000233159.97667.c3

75. Portenoy RK, Thomas J, Boatwright MLM, et al. Subcutaneous methylnaltrexone for the treatment of opioid-induced constipation in patients with advanced illness: a double-blind, randomized, parallel group, dose-ranging study. J Pain Symptom Manage. 2008;35 (5):458-468. doi:10.1016/j.jpainsymman.2007.12.005

76. Slatkin N, Thomas J, Lipman AG, et al. Methylnaltrexone for treatment of opioid-induced constipation in advanced illness patients. J Support Oncol. 2009;7(1):39-46.

77. GoodRx. Stop paying too much for your prescriptions. GoodRx. Published 2019. Available from: goodrx.com. Accessed October 24, 2019.
Drug Design, Development and Therapy

\section{Publish your work in this journal}

Drug Design, Development and Therapy is an international, peerreviewed open-access journal that spans the spectrum of drug design and development through to clinical applications. Clinical outcomes, patient safety, and programs for the development and effective, safe, and sustained use of medicines are a feature of the journal, which has also

\section{Dovepress}

been accepted for indexing on PubMed Central. The manuscript management system is completely online and includes a very quick and fair peer-review system, which is all easy to use. Visit http://www. dovepress.com/testimonials.php to read real quotes from published authors. 